ALEKSANDAR SIMONOVSKI, asistent-istraživač

Institut za nacionalnu istoriju

UDK 355:929 Трбић М.(093.2)

Skoplje, Grigor Prličev 3

94(497.17)"1947"(093.2)

\title{
HAPŠENJE MILIVOJA TRBIĆA U JANUARU 1947.
}

\begin{abstract}
APSTRAKT: $U$ članku je rekonstruisano hapšenje Milivoja Trbića (Milivoj Trbić) $)^{1}$ koje je izvršila UDB-a. Tekst sačinjava nekoliko delova: izvori koji su korišćeni, bekstvo Trbića iz redova NOV i PO Makedonije, mesta na kojima se skrivao i elaboraciju operacije njegovog pronalaženja i hapšenja.
\end{abstract}

Ključne reči: Milivoj Trbić, Gostiražni, Brailovo, Rilevo, Zrze, hapšenje, saslušanje

Podaci za rekonstrukciju događaja koji su povezani sa hapšenjem Milivoja Trbića ${ }^{2}$ navedeni su u izveštaju Uprave za državnu bezbednost (UDB) o toku operacije pronalaženja i hapšenja ${ }^{3}$ i u policijskim dosijeima UDB-e koja su vođena o Milivoju Trbiću, njegovoj nevenčanoj supruzi Zlati

${ }^{1}$ U dokumentaciji policijskog dosijea Milivoja Trbića (Milivoj Trbić) u Državnom arhivu Republike Makedonije srećemo i ime Milivoje. Državni arhiv Republike Makedonije, Skoplje (dalje: DARM), fond (dalje: f.) Republički sekretarijat unutrašnjih poslova /OZNUDB/ (dalje: RSUP/OZNA-UDB/), dos. 42200146 Trbić Vasilije Milivoje, AK 111/17. U optužnici od 28. januara 1943. i u presudi protiv pripadnika Ravnogorskog pokreta na teritoriji Makedonije od 16. juna 1943. od Skopskog vanrednog suda, Milivoj Trbić je naveden kao Voislav Trbić. Takav je slučaj i u jednom dokumentu Federalne komisije Makedonije za utvrđivanje zločina okupatora i njihovih pomoćnika od 30. juna 1945. Arhiv Jugoslavije, Beograd (dalje: AJ), f. Državna komisija za utvrđivanje zločina okupatora i njihovih pomagača (dalje: DK), F. br. 3875, dos. br. 1317, Rešenje o utvrđivanju zločina Vojislava Trbića u Drugom svetskom ratu, 30. jun 1945; Dokumentaciono odeljenje „Dr Velimir Brezoski“ pri Institutu za nacionalnu istoriju, Skoplje (dalje: DO „Dr Velimir Brezoski“), f. Ostavština prof. dr Velimira Brezoskog (dalje: Ostavština), kutija (dalje: kut.) 2, Optužnica od 28. januara 1943, 12; Političkite sudski procesi vo Skopje za vreme na bugarskata okupacija (1941-1944), izbor, voved i redakcija prof. d-r Vlado Ivanoski, Skopje 2009, 183, 186, 191. Mi u glavnom tekstu koristimo ime Milivoj budući da u/na dokumentima gde se on potpisivao, ističe njegov svojeručni potpis Milivoj Trbić Vojče. Ime Voislav ne odgovara pravom imenu Milivoja Trbića.

${ }^{2}$ Sin srpskog četničkog vojvode i poslanika u Skupštini Kraljevine Jugoslavije iz Prilepskog sreza, Vasilija Trbića.

${ }^{3}$ Izveštaj je napisan posle operacije. 
Mađoskoj i o određenom broju lica koja su imala kontakte sa Trbićem u vreme njegovog skrivanja. Podjednako značajni jesu dokumenti UDB-e pronađeni kod samog Milivoja Trbića a koji se ne nalaze $u$ njegovom policijskom dosijeu.

Prilikom analize dosijea najviše su korišćeni zapisnici UDB-e sa saslušanja određenog broja uključenih lica. Mada se prilikom obrade materijala postavilo pitanje verodostojnosti tih iskaza i to zbog okolnosti u kojima su dati, smatramo da taj materijal omogućava da se formira slika o temi rada.

Milivoj Trbić, pripadnik Ravnogorskog pokreta, bio je deo tročlane grupe koju je nadležni Gorski štab br. 110 sredinom 1942. uputio da organizuje pokret na teritoriji Makedonije. U periodu 1942-1944, Trbić je delovao u oblasti Azot, u prilepskoj okolini, i u oblasti Poreč i obavljao je sledeće dužnosti: šef Istaknutog dela Štaba 110 (kao takav bio je odgovoran za organizovanje Ravnogorskog pokreta na području Makedonije, desno od reke Vardara), pomoćnik komandanta Vardarske vojne oblasti, komandant Prilepske i Veleške brigade Porečkog korpusa Jugoslovenske vojske u otadžbini i odgovoran za finansijska sredstva Ravnogorskog pokreta u ovom rejonu. ${ }^{4}$

Treba napomenuti da Ravnogorski pokret, iako formiran i na teritoriji Makedonije, u Drugom svetskom ratu ovde nije bio značajan vojnopolitički faktor.

Krajem avgusta ili početkom septembra 1944, u prilepskoj okolini Narodnooslobodilački pokret (NOP) Makedonije pregovarao je sa Trbićem $\mathrm{u}$ duhu dogovora od 16. juna 1944. između Nacionalnog komiteta oslobođenja Jugoslavije (NKOJ) i Jugoslovenske kraljevske vlade, sa ciljem da se Trbić priključi Narodnooslobodilačkoj vojsci i partizanskim odredima (NOV i PO) Makedonije. ${ }^{5}$ Ubrzo posle pristupanja NOV i PO Makedonije, on beži iz njenih redova i o ovome događaju sam Trbić ima dve verzije. Prema prvoj, on se $u$ selu Nebregovo susreo sa političkim komesarom Glavnog štaba NOV i PO Makedonije, Borkom Temelkoskim-Liljkom (Borko Temelkoski-Liljakot), da bi posle toga istakao: „On mi reče da se

${ }^{4}$ DO „Dr Velimir Brezoski“, f. Ostavština, kut. 2, Zapisnik sa saslušanja Milivoja Vasila Trbića „Vojčeta“ 27. januara 1947, 1-6; Slavka Fidanova, Četničkata organizacija na Draža Mihajloviḱ vo Prilep i Prilepsko 1943-1944, Prilep i Prilepsko vo NOV 1944-15 maj 1945 godina: materijali od naučniot sobir održan na 14, 15. i 16 mart 1983 godina, kniga I/2, Skopje 1985, 264-267.

${ }^{5}$ Krste Krsteski, Pregovori so Vojče Trbiא́ i likvidiranje na negovata grupa vo Prilepsko, Prilep i Prilepsko vo NOV 1944-15 maj 1945 godina: materijali od naučniot sobir održan na 14, 15 i 16 maj 1983 godina, kniga treta, Skopje 1985, 254-256. 
pripremim i odem u bazu (...) on mi reče: 'Ti si vojnik i treba da izvršavaš naredbe, a treba i da odgovaraš jer si sam bez prava vršio mobilizaciju'. Ja sam se prividno složio, ali sam se uplašio jer su me zvali u bazu“. ${ }^{6}$ Prema drugoj verziji, Trbić je pobegao jer nije imao poverenja u NOV i PO Makedonije, plašeći se da ne bude ubijen kao organizator Ravnogorskog pokreta. ${ }^{7}$ Slušajući glasine da će biti streljan, posle kratkog boravka u prilepskom kraju sa Mađoskom i još dva lica otišao je u oblast Poreč nadajući se da će tamo naći svog poznanika Božidara Leševića. ${ }^{8}$ Njemu je prethodno napisao pismo i Lešević je trebalo da izvidi situaciju u kojoj se Trbić zatekao, a uz Leševićevo posredovanje, Trbić bi se predao NOV i PO Makedonije da bi mogao po drugi put da im se priključi. ${ }^{9}$

U oblasti Poreč, Trbić i Mađoska su odseli u selu Zrkle, kod ujaka njegove supruge Radovana, posle čega su se premestili kod Milosava Kostadinoskog gde su ostali više od mesec dana ${ }^{10}$ čekajući obaveštenje od Leševića. S obzirom da se to nije desilo, odlučili su da se skriju kod njene

${ }^{6}$ DARM, f. RSUP/OZNA-UDB/, dos. 42200146 Trbić Vasilije Milivoj, AK 111/17, Zapisnik sa saslušanja Milivoja Vasila Trbića „Vojčo“ 23. januara 1947. Iskaz Milivoja Trbića o mobilizaciji je oskudan da bi razumeli na šta se konkretno ukazuje.

${ }^{7}$ DO „Dr Velimir Brezoski“, f. Ostavština, kut. 2, Zapisnik sa saslušanja Milivoja Vasila Trbića „Vojčeta“ 27. januara 1947, 8.

${ }^{8}$ Božidar Lešević (Prokuplje, 1890 - ?). U drugoj polovini 1943. priključio se Ravnogorskom pokretu u oblasti Poreč - Makedonija. Posle pregovora u oblasti Poreč, krajem avgusta 1944, između 5. makedonske narodnooslobodilačke udarne brigade - Prilepske i Ravnogorskog pokreta u duhu Dogovora između NKOJ i Jugoslavenske kraljevske vlade od 16. juna 1944, pripadnici Ravnogorskog pokreta u oblasti Poreč stavili su se pod komandu NOV-a i PO-a Makedonije i formirana je 6. porečka narodnooslobodilačka brigada sastavljena od snaga Ravnogorskog pokreta i boraca 5. makedonske narodnooslobodilačke udarne brigade - Prilepske. Time je, u stvari, likvidiran Ravnogorski pokret u oblasti Poreč. U štabu 6. porečke narodnooslobodilačke brigade, Lešević je bio intendant. Iako Petar Pepeljugoski piše o Dušanu Leševiću, smatramo da se ime Dušan Lešević odnosilo na Božidara Leševića s obzirom da pri istraživanju delovanja Ravnogorskog pokreta u oblasti Poreč, nismo naišli na osobu Dušan Lešević. Petar Pepeljugoski, Nezaboravni godini (sé́avanja), Prilep 1982, 212$214,231$.

9 DARM, f. RSUP/OZNA-UDBA/, dos. 42200146 Trbić Vasilije Milivoje, AK 111/17, Zapisnik sa saslušanja Milivoj Vasil Trbić „Vojčo“ 23. januara 1947; dos. 47100147 Unerkova Dimko Zlata, AK 258/4, Zapisnik sa saslušanja Zlate Dimkove Mađoske (Zlata Dimkova Mađoska) 22. januara 1947, 4-5; dos. 47100147 Stankovski Veljan Angele, AK 247/8, Zapisnik sa saslušanja Angeleta Veljanovog Stankoskog (Angele Veljan Stankoski) 17-21. januara 1947, 1.

${ }^{10}$ Postoji i osoba Milosav Kostadin Videski iz sela Zrkle, koji je na saslušanju od UDB-e istakao da su u njegovu kuću novembra 1944. došli Trbić i Mađoska i ostali tri dana ili nije znao koliko tačno vremena. Očigledno je da su Milosav Kostadinoski i Milosav Kostadin Videski ista ličnost. DARM, f. RSUP/OZNA-UDB/, dos. 42201186 Videvski Kostadin Milosav, AK 111/18, Zapisnik sa saslušanja Miliosava Videskog Kostovog 8. decembra 1947, 2; Zapisnik sa saslušanja Milosava Videskog Kostovog 11. decembra 1947; Zapisnik sa saslušanja Miliosava Videskog Kostovog 27. januara 1948. 
majke u selu Samokov, gde su odseli nekoliko dana. Trbić i Mađoska su napustili Samokov jer njen otac nije hteo da ih primi pa su ih Atanas Ilievski ${ }^{11}$ i Vojče Miladino(v)ski, iz prilepskog sela Gostrižani, smestili u svoje selo. Trbić i Mađoska su se skrivali nekoliko godina po prilepskim selima Gostrižani, Brailovo, Rilevo i Zrze, koja su deo područja u severozapadnom delu Prilepa gde je za vreme rata delovao Ravnogorski pokret. Na saslušanju od strane UDB-e 27. januara 1947, Trbić je, kao najbliže saradnike $\mathrm{u}$ vreme dok se skrivao, naveo: Bogeta Veleskog (Boge Veleski), ${ }^{12}$ koji se susreće i kao Boge Župan, i Vasila Janevskog ${ }^{13}$ iz sela Brailovo, Atanasa Ilievskog, Petreta Trenkovski (Petre Trenkovski), koji se sreće kao Petre Maslar, iz sela Rilevo i Krsteta Markoskog (Krste Markoski) iz sela Krapa-Poreč. Obaveštenja o radu vlasti (održavanje konferencije i dr.), dobijao je najčešće od Janevskog, koji je bio sekretar mesnog narodnog odbora u selu Brailovo. ${ }^{14}$

Posle boravka u Gostrižanima decembra 1944, oni su se krili u nekoliko kuća. Prvo su se sklonili kod Vojčeta Mildino(v)skog i njegovog oca Miladina, Koleta ili Koneta Milošeskog ${ }^{15}$ i zatim kod njegovog brata Petreta Milošeskog (Petre Milošeski). Kod Petreta Milošeskog su boravili od aprila 1945. do aprila 1946. Ovde im se rodio sin, a loši uslovi života i Trbićeva strahovanja da ih zbog predugog prebivanja na jednom mestu mogu otkriti, bili su razlog da se premeste. ${ }^{16}$ Sledeće skloniše bilo im je kod

${ }^{11}$ Sreće se kao Atanas Čičevski, Atanas Čičovski, Tanasko Čičovski, Tane Ilie(v)ski i Tane Ilioski.

${ }^{12} \mathrm{U}$ prilepskom kraju prezimena ne završavaju na „vski“ nego na „ski“, međutim, pojavljuju se $\mathrm{u}$ dokumentima $\mathrm{u}$ varijanti sa „V“, zavisno od službenika koji je obrađivao dokumenat i zato se u ovom tekstu prezimena javljaju u obe varijante, npr. Stankoski i Stankovski. U obrađenoj dokumentaciji postoje i nedoslednosti u beleženju ličnih i očevih imena, usled nepoznavanja njihove transkripcije od strane službenika. Npr. Atansovski Gjorgji Todor u dosijeu ali u zapisniku je Todor Georgijev Atansoski.

${ }^{13}$ Sreće se kao Vasil Janeski, Vaslil Velkoski, Vasil Jone(v)ski i Vasilije Jankovski.

${ }^{14}$ DARM, f. RSUP/OZNA-UDB/, dos. 44101246 Velevski Atanas Boge, AK 182/23, Zapisnik sa dopunskog saslušanja Bogeta Atanasovog Veleskog 23. januara 1947; dos. 42200146 Trbić Vasilije Milivoje, AK 111/17, Informacije o potrazi za grupom Trbić - 24. aprila 1947, Zapisnik sa saslušanja Milivoj Vasil Trbić „Vojčo“ 23. januara 1947. DO „Dr. Velimir Brezoski“, f. Ostavština, kut. 2, Zapisnik sa saslušanja Milivoja Vasila Trbića „Vojčeta" 27. januara 1947, 8-10, 16.

${ }^{15}$ Prezime Milošeski se sreće kao Miloševski, Mološeski i Milošoski.

${ }^{16}$ DARM, f. RSUP/OZNA-UDB/, dos. 47100147 Unerkova Dimko Zlata, AK 258/4, Zapisnik sa saslušanja Zlate Dimkove Mađoske 22. januara 1947, 4, Zapisnik sa saslušanja Zlate Dimkove Mađoske 22. januara 1947, 6; dos. 42200146 Trbić Vasilije Milivoje, AK 111/17, Zapisnik sa saslušanja Milivoj Vasil Trbić „Vojčo“ 23. januara 1947, Provaljeni u vezi sa Vojčetom Trbićem -24. april 1947. U vezi sa istragom grupe Trbić provaljena su sledeća lica - 24. aprila 1947; dos. 47100949 Ilievski Vasil Atanas, AK 247/13, Zapisnik sa saslušanja Taneta Vasilevog Ilievskog (Tane Vasil Ilievski) 21. januara 1947, 2-3. 
Trenkovskog i njegovog oca Blažeta Maslaroskog, koji se sreće kao Blaže Maslar, u selu Rilevu. ${ }^{17}$ Tu su ostali samo nekoliko dana zbog straha da ih ne provale prevoznici stočnim kolima, sa kojima je sarađivao Petre. Posredovanjem Trenkovskog, Veleskog i Janevskog, Trbić je prebačen u kuću Todora Cvetanoskog ${ }^{18} \mathrm{u}$ Brailovo. Boge Veleski i Dragan Aleksoski u to selo dovode i Mađosku sa detetom. O vremenu boravka u kući Cvetanoskog, podaci su različiti: do 27. oktobra 1946, nekoliko dana posle 27. oktobra i novembar $1946 .{ }^{19}$ Najtačnijim treba smatrati datum 27. oktobar, a $\mathrm{u}$ prilog tome idu i podaci sa saslušanja sina Todora Cvetanoskog, Temelka (Temelko), ${ }^{20}$ kao i Todora Atanasoskog koji je u jednoj prilici kod Todora Cvetanoskog video Trbića, Mađosku i dete, razgovarao sa Trbićem da bi na saslušanju u UDB-i 24. januara 1947. istakao: „Vojče (Milivoj Trbić-Vojče - prim. aut.) stanovao je kod Todora do Petrovdana (u stvari do Petkovdana - prim. aut.) 1946. god., odatle se premestio zato jer je Todoru bila slava i plašio se da ga ne vide gosti koji će dolaziti“. ${ }^{21}$

Sledeća utočišta do sredine januara 1947. bila su im u Brailovu kod Bogeta Veleskog, u selu Zrze kod Angeleta Stankoskog (Angele Stankoski) ${ }^{22}$ i u Rilevu kod Petreta Trenkovskog. Dok su se Trbić i Mađoska krili u Rilevo u kući Petreta Trenkovskog i Blažeta Maslaroskog, decembra 1946. njima se pridružuje Vasil Janevski sa nevenčanom suprugom Stojnom Petrovom (Stojna Petrova). ${ }^{23}$ Značajan podatak je da su Trbić i Trenkovski

${ }^{17}$ Prema UDB-i, pre Trenkovskog, Trbić se krio 2-3 dana kod Risteta Miloševskog (Riste Miloševski) u selu Gostrižani. DARM, f. RSUP/OZN-UDB/, dos. 42200146 Trbić Vasilije Milivoje, AK 111/17, U vezi sa istragom grupe Trbić su provaljena su sledeća lica - 24. april 1947.

${ }^{18}$ Sreće se kao Todor Bačkoski, Todor Bačko, Todor Petrovski i Todor Petrov Cvetanoski.

${ }^{19}$ DARM, f. RSUP/OZNA-UDB/, dos. 4410246 Velevski Atanas Boge, AK 182/23, Zapisnik sa saslušanja Bogeta Atanasovog Veleskog 19-20. januara 1947, 2; dos. 47100147 Unerkova Dimko Zlata, AK 258/4, Zapisnik sa saslušanja Zlate Dimkove Mađoske 22. januara 1947, 6; dos. 42200146 Trbić Vasilije Milivoje, AK 111/17, U vezi sa istragom grupe Trbić provaljena su sledeća lica -24. april 1947, Zapisnik sa saslušanja Petkane Cvetanove Arizankoska 4. januara 1947, 2.

20 DARM, f. RSUP/OZNA-UDB/, dos. 44100147 Petrevski Todor Temelko AK 190/10, Zapisnik sa saslušanja Temelka Todorovog Petreskog (Temelko Petreski) 25. januara 1947, 1.

21 DARM, f. RSUP/OZNA-UDB/, dos. 47100147 Atanasovski Gjorgji Todor, AK 260/12, Zapisnik sa saslušanja Todora Georgijevog Atanasoskog 24. januara 1947, 2.

Kockar.

${ }^{22}$ Sreće se kao Angele Veljanov, Angele Veljanoski, Angele Kockaroski i Angele

${ }^{23}$ DARM, f. RSUP/OZNA-UDB/, dos. 42200146 Trbić Vasilije Milivoje, AK 111/17, Informacije o potrazi za grupom Trbić - 24. april 1947, Zapisnik sa saslušanja Blažeta Trajanoskog Maslaroskog (Blaže Trajanoski Maslaroski) 22. januara 1947; dos. 44101246 Velevski Atanas Boge, AK 182/23, Zapisnik sa saslušanja Bogeta Atanasovog Velevskog (Boge 
iskopali zemunicu u zemlji za skrivanje u slučaju da vlasti budu vršile pretres, ali zbog delikatne situacije straža je čuvana i danju i noću. Poslednje mesto na kojem su boravili Trbić, Mađoska, Janevski i Petrova bilo je u selu Zrze kod Taseta Kostadinoskog (Tase Kostadinoski), koji se sreće kao Tase Sopodoski i Tase Sopot. ${ }^{24}$

U to vreme, Komunistička partija Jugoslavije (KPJ) pri formiranju novog državnog i društvenog sistema držala je sve konce u svojim rukama i bila odlučna da eliminiše sve političke protivnike, koje je smatrala neprijateljima zemlje i naroda. ${ }^{25} \mathrm{U}$ okviru takve pozicije KPJ, Trbić je trebalo da odgovara za organizovanje Ravnogorskog pokreta na teritoriji Makedonije kao protivnik Narodnooslobodilačke borbe, a njegovo bekstvo iz NOV-a i PO-a Makedonije biće tretirano kao odmetanje od nove vlasti. ${ }^{26}$ Federalna komisija Makedonije za utvrđivanje zločina okupatora i njihovih pomagača optuživala je Trbića i da je jedna četa pod njegovim vođstvom avgusta 1943. stigla u selo Krapa i odvela Taseta Petrovog Desoskog (Tase Petrov Desoski), Đuru Trenevog Velkoskog i Nikolu Mitkoskog, od kojih su prva dvojica ubijeni a Nikola Mitkoski pušten. Zbog brojnih zločina koji su mu pripisivani, Komisija je tražila Trbićevu ekstradiciju. Prema informacijama kojima je raspolagala nije se moglo utvrditi mesto gde se on nalazi i smatralo se da je verovatno pobegao u Grčku ili u Englesku. ${ }^{27}$

U vezi sa ubistvom pomenutih lica, Trbić je na saslušanju 27. januara 1947. izjavio: „U selu Krapa znam da su zaklani seljani Đuro i Tase. Seljani iz s. Krapa su došli kod mene i rekli su mi da postoji opasnost za rad (Ravnogorskog pokreta - prim. aut.) u njihovom selu od gore navedenih seljana. Zato sam poslao: Atanasa Đorđevića i Metodija iz Crešneva, Milana Saveskog, Miomira iz Dobrog Dola, Svetozara iz Drvodela, i isti su otišli i zaklali Đuru i Taseta kao naše neprijatelje. To se desilo u septembru 1943. godine." 28

Atanasov Velevski) 19-20. januara 1947; dos. 47100147 Unerkova Dimko Zlata, AK 258/4, Zapisnik sa saslušanja Zlate Dimkove Mađoske 22. januara 1947, 5; dos. 47100147 Stankovski Veljan Angele, AK 247/8, Zapisnik sa saslušanja Angeleta Veljanovog Stankoskog 17-21. januara 1947, 3. DO „Dr Velimir Brezoski“, f. Ostavština, kut. 2, Zapisnik sa saslušanja Milivoja Vasila Trbića „Vojčeta“ 27. januara 1947, 16.

24 DARM, f. RSUP/OZNA-UDB/, dos. 42200146 Trbić Vasilije Milivoje, AK 111/17, Zapisnik sa saslušanja Blažeta Trajanoskog Maslaroskog 22. januara 1947, U vezi sa istragom grupe Trbić provaljena se sledeća lica - 24. april 1947.

${ }^{25}$ Momčilo Pavlović, Za Tita ili za kralja: izbori za Ustavotvornu skupštinu 11. novembra 1945, Beograd 2007, 11.

${ }^{26}$ Nova Makedonija, 12. jun 1947, 7.

${ }^{27}$ AJ, f. DK, F. br. 3875, Dos. br. 1317, Rešenje o utvrđivanju zločina Vojislava Trbića u Drugom svetskom ratu, 30. jun 1945.

${ }^{28}$ DO „Dr Velimir Brezoski“, f. Ostavština, kut. 2, Zapisnik sa saslušanja Milivoja Vasila Trbića „Vojčeta“ 27. januara 1947, 7. 
Odeljenje za zaštitu naroda (OZNA) počelo je u Makedoniji operaciju pronalaženja i hvatanja Trbića. U početku se tome nije pristupilo ozbiljno, na podatke dobijene od saradnika nije se obraćala veća pažnja niti su detaljno analizirani, nisu preduzimane sve mere da se ubace agenti u sredinu koja bi mogla da pomaže Trbića. Saradnici su vrbovani na osnovu patriotizma i bili su uglavnom članovi Komunističke partije Makedonije, lica koja nisu mogla da imaju kontakt s Trbićem i njegovom sredinom, pa su informacije do kojih su dolazili bile neprecizne. U više navrata, pretresana su sela i sprovođena je istraga, ali to nije davalo rezultate. $^{29}$

Posle prvih neuspeha promenjen je metod rada i vrbovano je lice (agent) koje je za vreme rata bilo pod Trbićevom komandom u Ravnogorskom pokretu. Pretpostavljalo se da će ta osoba veoma lako uspostaviti vezu s njim ukoliko se nalazio u Makedoniji. Lice je vrbovano za novac, trebalo je da se poveže sa Trbićevim jatacima i da im se stavi na raspolaganje. Razrada plana je počela u leto 1946. Sastanci su održavani u oblasti Poreč i u okolini Prilepa. Agent je dostavljao razne podatke, tvrdio da je uspostavio vezu sa Trbiću najbliskijom osobom, koja mu kao meru opreza još uvek nije otkrivala njegovo sklonište. Ovo je dovelo do zaključka da se istraga kreće u pravom smeru, odnosno smatralo se da se Trbiću ulazi $\mathrm{u}$ trag. Jednom je agent dostavio izveštaj o konkretnom vremenu i mestu održavanja sastanka sa osobama iz porečkog i prilepskog kraja, pri čemu je naveo i lica koja treba da prisustvuju. Podaci iz dojave smatrani su tačnim, jer su navedene ličnosti tretirane $u$ UDB-i kao glavne veze sa Trbićem ili njegovom sredinom, a s druge strane, očekivalo se da Trbić preuzme šire akcije. $^{30}$

Ovakvo izveštavanje izazvalo je zadovoljstvo kod operativne grupe UDB-e, ali „sve je ovo bilo kratkog daha“. Na osnovu nedovoljno analiziranih informacija organizovana je akcija u kojoj su učestvovali oficiri UDB-e, vojska i milicija. Sa velikom pažnjom bilo je blokirano mesto na kojem je trebalo da se održi sastanak, ali „sve je to bilo uzalud - nigde nikoga“. Posle ove neuspešne akcije „izveštaji agenta i dalje su redovno tekli“, ali se na njegove izveštaje sada gledalo sa oprezom. Do tog momenta nisu proveravani delovi izveštaja, a kada se „već posumnja i uvidi da može biti da gubimo vreme na dobro legendirane agentove izveštaje (verovatno se misli na "lažirane“ izveštaje - prim. aut.), pristupilo se analizi i proveravanju“. Agent nije znao da se njegovi izveštaji primaju s rezervom i produžio je da sastavlja lažne izveštaje, da bi se na kraju „dokazalo da agent laže“. Istraga nije raspolagala podacima o Trbićevom kretanju, niti

${ }^{29}$ DARM, f. RSUP/OZNA-UDB/, dos. 42200146 Trbić Vasilije Milivoje, AK 111/17, Likvidacija bande Vojčeta Trbića, 2.

${ }^{30}$ Isto, 3. 
konkretnim informacijama o licima koja su ga krila, tako da je njegovo hapšenje prerastalo u sve aktuelniji problem. Pristupilo se stvaranju nove obaveštajne mreže, tako što su 20 dana vrbovani novi agenti sa kojima su svakodnevno održavani sastanci. Od posebne važnosti bilo je da se barem približno otkrije mesto na kojem se krio Trbić. Većina informacija upućivala je da se Trbić nalazi na prilepskom području. ${ }^{31}$

Da bi utvrdila mesto skrivanja, UDB-a je krenula u potragu za licem koje će joj dostavljati takve informacije. Mreža je prikupljala sve što se govorilo po selima, "ali nikako da dođemo do bližih podataka“. Napori UDB-e su napokon dali rezultat posle analize izveštaja saradnika iz Brailova, koji će im predočiti lice koje će se pokazati kao ključni ispitanik i čije će informacije dovesti do pronalaženja Trbića. Saradnik je izvestio UDB-u da je od svoje kćerke doznao kako je Dušan, sin Vasila Janevskog, zaljubljen u devojku iz Brailova, prijateljicu njegove kćerke. Dušan je ovoj devojci kazao da je njegov otac, pre nego je pobegao, odneo radio-aparat na popravak u Prilep i, kada je aparat bio gotov, otišao je u Rilevo i više se nije vratio. Ovu informaciju UDB-a je smatrala ključnom i pretpostavljalo se da se i Trbić krije u Rilevu. Zbog toga je UDB-a odlučila da tu devojku tajno uhapsi. ${ }^{32}$ Reč je o Petkani Arizankoskoj koja je 4. januara 1947. saslušana u UDB-i Prilepa. Prema njenom iskazu, ona je o Trbiću znala od Dušana, a u proljeće 1946. kada je sa ocem bila u kući Cvetanoskog, lično je videla Trbića, Mađosku i njihovo dete. ${ }^{33}$

Arizankoska je svedočila da se Dušanov otac u svojoj kući sreo sa osobom koju je UDB-a već „registrirala kao glavnog jataka“ Milivoja Trbića i dalja istraga se usredsredila na hapšenje ovog lica. ${ }^{34} \mathrm{U}$ tajnosti je uhapšeno prokazano lice koje će otkriti lokaciju u Rilevu na kojoj se Trbić nalazio. U izveštaju UDB-e navodi se sledeće: „(...) dobili smo lice gde je trebalo brzo da se deluje, tačnije zavisilo je da li će mesto biti provaljeno ili ne (...). Vreme nije smelo da se gubi, zato je odlučeno da se u što kraćem roku utvrdi gde je banda. Još iste noći, s neprekinutim radom se potvrdilo i otkrilo gde se skriva naoružana grupa, već smo naučili u kojem selu i gde se nalaze na zimovanju". ${ }^{35}$ Uhapšeno lice je Boge Veleski koji je bio u istražnom zatvoru od 14. januara $1947 .^{36}$

31 Isto.

${ }^{32}$ Isto, 4.

33 DARM, f. RSUP/OZNA-UDB/, dos. 12271 Arizankoska Cvetan Petkana, AK 410/6, Zapisnik sa saslušanja Petkane Cvetanove Arizankoska 4. januara 1947.

${ }^{34}$ DARM, f. RSUP/OZNA-UDB/, dos. 42200146 Trbić Vasilije Milivoje, AK 111/17, Likvidacija bande Vojčeta Trbića, 4.

35 Isto.

${ }^{36}$ DO „Dr Velimir Brezoski“, f. Ostavština, kut. 2, Presuda od 13. juna 1947, 1. 
On je na saslušanju u UDB-i 15. januara 1947, po hronološkom redu naveo mesta i lica kod kojih se Trbić krio od aprila 1946, da bi na kraju otkrio i tačno mesto na kojem se krije: „On je kod Blažeta Maslara (...) Ovo niko drugi iz našeg sela (Brailovo - prim. aut.) ne zna. Ja znam zato jer za vreme Vojčetovog kretanja (Milivoj Trbić-Vojče - prim. aut.) ja sam bio u raznim stanovima i uostalom bio sam pre 18 dana kod Blažeta Maslara, on je bio tamo i nije bilo pomena o premeštanju, zato prema svemu ovome tvrdim da je tamo (...) $U$ istom stanu nalazi se i novi begunac Vasil V. Joneski (Vasil Velkov Janevski - prim. aut.) zajedno sa ljubavnicom". Od oružja su imali dve puške i jedan revolver. ${ }^{37}$

Iskaz Veleskog o tačnoj lokaciji na kojoj se skrivao Trbić podudara se sa izveštajem UDB-e, ali postoji nejasnoća u poređenju sa zapisnikom sa saslušanja Veleskog od 15. januara 1947. Ukoliko je deo „Vreme nije smelo da se gubi, zato je odlučeno da se u što kraćem roku utvrdi gde je banda. Još iste noći, s neprekinutim radom se potvrdilo i otkrilo gde se skriva naoružana grupa, već smo naučili u kojem selu i gde se nalaze na zimovanju“ datiran 14. januarom 1947, od kada je Veleski bio u istražnom zatvoru, i budući da takvo pisanje odslikava aktivnost UDB-e da otkrije gde se krije Trbić, u zapisniku sa saslušanja Veleskog nedostaje datum 14. januar zato što je zapisnik datiran 15. januarom 1947. Citiramo: „Rađeno pod punomoći U. D.B. Prilep na 15-I-1947 god."38 Ili je možda zapisnik datiran samo na 15. januar jer je tog dana provaljen Trbić, a to je bilo najvažnije što je trebalo uneti u zapisnik.

Iskaz Veleskog je omogućio UDB-i da te noći organizuje akciju. Mesto je bilo opsednuto pred zoru, a akcija je počela posle svitanja. Iako su pri pretresu u Rilevu na imanju Trenkovskog i Maslaroskog nađeni kokarda, šajkača, konzerve i drugo, tražena lica nisu pronađena jer su se krila u zemunici koja nije bila otkrivena. ${ }^{39}$ Prilikom ispitivanja domaćini nisu priznali da su skrivali tražene osobe: „Bili smo prinuđeni da se vratimo u Prilep i produžimo sa istragom nad jatacima. Akcija je propala i ljudstvo je bilo povučeno. U toku dana beše provaljeno i skrovište". ${ }^{40}$

${ }^{37}$ DARM, f. RSUP/OZNA-UDB/, dos. 42200146 Trbić Vasilije Milivoje, AK 111/17, Zapisnik sa saslušanja Bogeta Atanasovog Veleskog 15. januara 1947.

${ }^{38}$ Isto.

${ }^{39}$ Prema Mađoskoj, prethodno je Trenkovski doznao da su u Gostrižanima i drugim selima bile blokade i zato je licima koja su se krila kod njega rekao da se pretres verovatno vrši i u Rilevu. Tako su u skrovište donete potrebne stvari, ali vojska je došla tek naredne večeri oko ponoći. Čim je primećena, lica koja su se krila oko 02:00 časova otišla su u skrovište. DARM, f. RSUP/OZNA-UDB/, dos. 47100147 Unerkova Dimko Zlata, AK 258/4, Zapisnik sa saslušanja Zlate Dimkove Mađoske 22. januara 1947, 6.

${ }^{40}$ DARM, f. RSUP/OZNA-UDB/, dos. 42200146 Trbić Vasilije Milivoje, AK 111/17, Likvidacija bande Vojčeta Trbića, 4-5. 
Skrovište je bilo napravljeno po ideji Trbića, koji je odabrao lokaciju gde se zimi sklanjala stoka. Zemunica se nalazila ispod kotara za skrivanje svinja, a njen ulaz su zatvarala dva teška kamena. Ovako prilagođeni ulaz za kratko vreme mogao je da se pokrije đubretom stoke i ostalim, što nije izazivalo sumnju da bi se tu moglo nalaziti skrovište. Sama zemunica na dubini od dva metra, sa podzidanim uskim hodnikom, bila je iskopana pored zida, a u slučaju nedostatka vazduha na zidu je postojao kamen koji se mogao lako skloniti i vratiti u prvobitan položaj. Takva kamuflaža je omogućila da, i pored toga što se pri pretresu kopalo u dvorištu i prevrtalo đubre, zemunica ostane neotkrivena. O daljem toku potrage, izveštaj UDBe navodi: „Kad smo već doznali od jataka gde se nalazi skrovište, ponovo se otišlo na mesto ali već je bilo kasno, Vojče (Milivoj Trbić-Vojče - prim. aut.) sa svojom naoružanom grupom je bio otišao". Akcija se ubrzo nastavila jer se smatralo da bi se Trbić i lica koja su se krila s njim mogli prebaciti u oblast Poreč.

Trbić, Mađoska, Janevski i Petrova su na kraju uhapšeni $u$ prilepskoj okolini, odnosno: „Pre da odu iz mesta gde su bili blokirani (u selu Rilevo, prim. aut.) rekli su jatakovoj ženi da idu u selo Zrze (...) i čak odredili kod koga. U bezizlaznoj situaciji ovaj podatak nam je pomogao da ih još istog dana uhvatimo". Kuća Taseta Kostadinoskog u selu Zrze je zaposednuta, posle čega je izvršen upad i Trbić, Mađoska, Janevski i Petrova su uhapšeni bez borbe. ${ }^{41}$

O Trbiću postoji podatak da je bio u istražnom zatvoru od 16 . januara 1947, Janevski od 18. januara 1947, a Mađoska od 11. juna $1947 .{ }^{42}$ Postoje i dokumenti koji datiraju iz ratnog perioda (1942-44), naknadno potpisani Trbićevom rukom 17. januara 1947: "Nađeno kod mene" i "Nađeno kod mene pri pretresu“". ${ }^{3}$ Sačuvan je i podatak prema kojem je hapšenje izvršeno 18. januara $1947 .{ }^{44}$ Pozivajući se na 17. januar 1947, kako je moguće da hapšenje bude izvršeno 18. januara? Radi se o kolektivnom hapšenju Trbića, Mađoske, Janevskog i Petrove o čemu piše i

${ }^{41}$ Isto; Informacije o potrazi za grupom Trbić - 24. april 1947.

${ }^{42}$ DO „Dr Velimir Brezoski“, f. Ostavština, kut. 2, Presuda od 13. juna 1947, 1.

43 DARM, f. RSUP/OZNA-UDB/, dos. 42200146 Trbić Vasilije Milivoje, AK 111/17, Priznanica za 5 francuskih napoleona u zlatu i Priznanica za 5 funti u zlatu, 6. juni 1944; Pismo za Vojčeta Trbića, 1. septembar 1944. DO „Dr Velimir Brezoski“, f. Ostavština, kut. 2, Lični dokumenti Vojčeta Trbića (original), Pismo Vasilija Trbića sinu Vojčetu Trbiću (original i prepis) od 15. februara 1943, Naredba komandanta Vardarske vojne oblasti br. 184 od 19. jula 1944, Račun za Istaknuti deo Štaba 110 za period 1943-44.

${ }^{44}$ DARM, f. RSUP/OZNA-UDB/, dos. 42200146 Trbić Vasilije Milivoje, AK 111/17, Do Okružnog tužilaštva u Bitolju, 20. januara 1947; Rešenje o određivanju istražnog zatvora, 3. februara 1947. 
sama UDB-a. ${ }^{45}$ Za datum hapšenja uzimamo 16. januar: Trbić je tada već bio $\mathrm{u}$ istražnom zatvoru i ovo je jedini datum koji ima dodirne tačke sa njihovim hapšenjem. Od kako je Veleski na saslušanju od 15. januara 1947. naveo da se Trbić nalazi u Rilevo, UDB-a je već te noći preduzela mere. Mesto je zaposednuto pred zoru, akcija je počela posle svitanja, izvršen je upad kod Trenkovskog i Maslaroskog. U toku dana (16. januara) otkriveno je skrovište, istog dana UDB-a je upala u Zrze kod Kostadinoskog i izvršila hapšenje. Dokaz hapšenja od 16. januara 1947. jeste i činjenica da je Petar Trenkovski bio u istražnom zatvoru od ovog datuma. ${ }^{46}$

Na sudskom procesu u Skoplju održanom od 11. do 13. juna 1947. Trbić je za krivično delo protiv naroda i države osuđen na kaznu smrti streljanjem, trajan gubitak političkih i građanskih prva i konfiskaciju celokupne imovine. ${ }^{47}$ Potom je podneta žalba na presudu, kao i molba za njegovo pomilovanje. Presudu je potvrdio Vrhovni sud Narodne republike Makedonije, a molbu za pomilovanje je odbio Prezidijum Narodne skupštine FNRJ, posle čega je 24. septembra 1947. izvršena egzekucija. ${ }^{48}$

Usled nedostataka izvora ne može se odrediti kada je tačno započela operacija OZN-e/UDB-e na pronalaženju Trbića i njegovom hapšenju, ali je jedno sigurno: u leto 1946. ta operacija je već bila u toku. Nekoliko godina skrivanja i promene Trbićevog mesta boravka svedoče o aktivnosti lica koje su ga skrivala uprkos operativnom radu OZN/UDB-e. Izveštaji saradnika iz Brailova otvorili su UDB-i put, a informacije saradnika i iskaz Arizankoske pokazali su se veoma važnim za sprovođenje operacije. UDB-a je usmerila svoje delovanje na hapšenje i saslušanje Veleskog, koji je otkrio tačno mesto skrivanja Milivoja Trbića u Rilevu. Na osnovu svedočenja da se premestio iz Rileva u Zrze, Trbić je konačno bio uhapšen.

${ }^{45}$ DARM, f. RSVR/OZNA-UDB/, dos. 42200146 Trbić Vasilije Milivoje, AK 111/17, Informacije o potrazi za grupom Trbić - 24 april 1947, Provaljeni u vezi sa Vojčetom Trbićem - 24. april 1947; dos. 47100148 Todor Tasev Petrevski, AK 256/11, Podaci o licu Todor Tasev Sopodovski iz sela Zrze, 26. januar 1948.

${ }^{46}$ DO „Dr Velimir Brezoski“, f. Ostavština, kut. 2, Presuda od 13. juna 1947, 1.

${ }^{47}$ Isto, 1-2, 4-6.

${ }^{48}$ DARM, f. RSUP/OZNA-UDB/, dos. 42200146 Trbić Vasilije Milivoje, AK 111/17, Presuda Vrhovnog suda NR Makedonije za održani pretres od 5. jula 1947; Zapisnik o izvršenju smrtne kazne nad Milivojem Trbićem, Skoplje, 24. septembar 1947. 
Aleksandar Simonovski

THE ARREST OF MILIVOJ TRBIĆ IN JANUARY 1947

\section{Summary}

This article has an aim to make a reconstruction of the arrest of Milivoj Trbić. He was arrested by the Administration of State Security on January 16, 1947 in the Prilep village Zrze. Two phases characterize the operation in Macedonia for locating and arrest of Trbic. The first phase is the period when the Department for Protection of the People was receiving incorrect reports from its contributors about the locations where Trbic could be. In the summer of 1946 was recruited a contributor with the idea that he could easily establish a contact with Trbić. This contributor submitted reports, but they were false. After that, began the formation of a new intelligence network which was supposed to find the exact or the approximate place of the hiding of Trbić. During the second phase, the Administration of State Security received a report from its contributor from the Prilep village Brailovo. According that report, in the beginning of January 1947 Petkana Arizankoska was arrested and she was the key examinee whose information was of great importance to the successful completion of the operation. In that way, in the middle of January 1947 was arrested Boge Veleski as a close contributor of Milivoj Trbić and he revealed the place where Trbić was hiding in the Prilep village Rilevo. Because of this, the operation continued in Rilevo, and finally, the Administration of State Security realized the epilogue in the village Zrze. 